\section{Case Reports in Neurology}

\begin{tabular}{l|l}
\hline DOI: 10.1159/000479730 & $\begin{array}{l}\text { C } 2017 \text { The Author(s) } \\
\text { Published by S. Karger AG, Basel } \\
\text { Published onlIne: Uctober 16, } 2017\end{array} \quad \begin{array}{l}\text { Karger } \\
\text { wwarger.com/crn }\end{array}$
\end{tabular}

This article is licensed under the Creative Commons Attribution-NonCommercial 4.0 International License (CC BY-NC) (http://www.karger.com/Services/OpenAccessLicense). Usage and distribution for commercial purposes requires written permission.

\title{
Stroke in a Young Man Secondary to Paroxysmal Atrial Fibrillation and Thyrotoxicosis: A Case Report
}

\author{
Rodrigo Bazan ${ }^{a}$ Thiago Dias Fernandes ${ }^{a}$ \\ Gláucia Maria Ferreira da Silva Mazetob \\ Mariângela Esther Alencar Marques ${ }^{c} \quad$ Gabriel Pereira Braga ${ }^{a}$

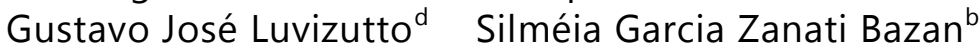 \\ aDepartment of Neurology, Psychology and Psychiatry, Botucatu School of Medicine, \\ Universidade Estadual Paulista Júlio de Mesquita Filho, São Paulo, Brazil; ${ }^{\mathrm{b}}$ Department of \\ Internal Medicine, Botucatu School of Medicine, Universidade Estadual Paulista Júlio de \\ Mesquita Filho, São Paulo, Brazil; 'Department of Pathology, Botucatu School of \\ Medicine, Universidade Estadual Paulista Júlio de Mesquita Filho, São Paulo, Brazil; \\ ${ }^{\mathrm{d}}$ Department of Applied Physical Therapy, Institute of Health Sciences, Federal University \\ of Triângulo Mineiro, Uberaba, Brazil
}

\section{Keywords}

Stroke $\cdot$ Atrial fibrillation · Thyrotoxicosis · Total thyroidectomy

\begin{abstract}
We report a case of a male patient with stroke caused by atrial fibrillation (AF) due to thyrotoxicosis. At hospital admission, he presented hypertension and AF. Magnetic resonance imaging confirmed a right-side ischemic area. The thyrotoxicosis was confirmed by thyroid function and thyroid scintigraphy that showed goiter with diffuse hypercaptation. The patient was treated with tapazole and total thyroidectomy, and pathological findings suggested Graves' disease. Hyperthyroidism is associated with increased supraventricular ectopic activity in patients with a normal heart, and may be an important causal link between hyperthy-
\end{abstract}




\section{Case Reports in Neurology}

Case Rep Neurol 2017;9:228-233

DOI: $10.1159 / 000479730$

Bazan et al.: Stroke in a Young Man Secondary to Paroxysmal Atrial Fibrillation and

Thyrotoxicosis: A Case Report

roidism and AF. The patient experienced significant clinical improvement, but presented long-term neuropsychiatric disorders.

(C) 2017 The Author(s)

Published by S. Karger AG, Basel

\section{Introduction}

Thyrotoxicosis is a rare thyroid dysfunction, with an annual incidence of $0.5-1.4$ cases/1,000 individuals, and is predominant in women (10:1). It is characterized by a series of adrenergic events, which can affect all organs and body systems, particularly the heart. Atrial fibrillation (AF) is the most common arrhythmia observed in patients with thyrotoxicosis and is reported in $15 \%$ of patients [1-2]. We report the case of a male patient who experienced stroke due to paroxysmal AF due to thyrotoxicosis, and previous reports have been summarized in Table 1.

\section{Case Report}

\section{Clinical Summary}

Forty-five days before admission to the hospital, a Caucasian 41-year-old male patient developed sweating, palpitations, and anxiety. Ten days prior to admission, the symptoms exacerbated with left paresthesia progressing to left hemiparesis, predominantly brachifacial. He had no relevant personal or family medical history. Upon admission to the hospital, he presented mild hypertension and cardiac rhythm of AF and psychiatric manifestations such as visual hallucinations. Physical examination revealed a slightly increased thyroid size. Brain magnetic resonance imaging confirmed an ischemic area on the right side of the frontoparietal region (Fig. 1), whereas the duplex carotid and magnetic resonance angiography of the cerebrovascular system yielded normal findings. The patient underwent anticoagulation treatment with warfarin (5 mg/day) 1 year after ictus and was investigated for stroke etiology.

\section{Pathological Findings}

Tests for inflammatory activity, lipid profile, serology for HIV, syphilis, Chagas disease, as well as cerebrospinal fluid were normal. One month after admission, thyrotoxicosis was confirmed through assessment of thyroid function (TSH: $<0.004 \mu \mathrm{UI} / \mathrm{mL}$ ) and thyroid scintigraphy that revealed goiter with diffuse hypercaptation. Initially, the patient was treated with tapazole $(60 \mathrm{mg} /$ day) and then underwent total thyroidectomy, from which the pathological findings confirmed lymphocytic thyroiditis, suggesting Graves' disease (Fig. 2). During the monitoring period, the patient partially recovered from the motor and sensitive deficits with a modified Rankin scale (mRS) score of 2, and the cardiac rhythm reversed to sinus rhythm. 


\section{Case Reports in Neurology}

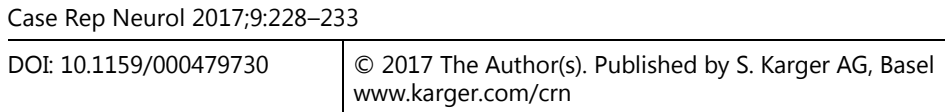

Bazan et al.: Stroke in a Young Man Secondary to Paroxysmal Atrial Fibrillation and Thyrotoxicosis: A Case Report

\section{Follow-Up and Outcomes}

After total thyroidectomy, the patient required continuous T4 replacement therapy. At 1 year of follow-up, the patient was independent in daily life activities (mRS 1), and his Barthel index was 90.

\section{Discussion}

It is well established that $\mathrm{AF}$ increases the risk of stroke. In the Framingham study, chronic AF was associated with an elevated risk of stroke; AF in the absence of rheumatic heart disease was associated with a $>5$-fold increase in stroke occurrence. Hyperthyroidism is associated with augmented supraventricular ectopic activity in patients with healthy hearts, and the activation of arrhythmogenic foci by elevated thyroid hormones may be an important causal link between hyperthyroidism and AF [3, 4]. In relation to psychiatric manifestations, studies suggest complex interactions between thyroid hormones and neurotransmitter circuits of the central nervous system [5]. This report aims to emphasize the importance of thyropathy screening examinations even in young men.

\section{Conclusions}

We have reported the case of a male patient with stroke due to paroxysmal AF due to thyrotoxicosis. We suggest that the thyroid crisis may be a determining factor in cerebrovascular diseases.

\section{Statement of Ethics}

All patients included in this study consented to the publication of the case report.

\section{Disclosure Statement}

The authors declare no conflicts of interest.

\section{References}

1 Bielecka-Dabrowa A, Mikhailidis DP, Rysz J, Banach M: The mechanisms of atrial fibrilation in hyperthyroidism. Thyroid Res 2009;2:4.

-2 Siu CW, Pong V, Zhang X, Chan YH, Jim MH, Liu S, Yiu KH, Kung AW, Lau CP, Tse HF: Risk of ischemic stroke after new-onset atrial fibrillation in patients with hyperthyroidism. Heart Rhythm 2009;6:169173.

- 3 Faber J, Wiinberg N, Schifter S, Mehlsen J: Haemodynamic changes following treatment of subclinical and overt hyperthyroidism. Eur J Endocrinol 2001;145:391-396.

4 Petersen P, Hansen JM: Stroke in the thyrotoxicosis with atrial fibrillation. Stroke 1988;19:15-18. 


\section{Case Reports in Neurology}

Bazan et al.: Stroke in a Young Man Secondary to Paroxysmal Atrial Fibrillation and

Thyrotoxicosis: A Case Report

5 Swee du S, Chng CL, Lim A: Clinical characteristics and outcome of thyroid storm: a case series and review of neuropsychiatric derangements in thyrotoxicosis. Endocr Pract 2015;21:182-189.

-6 Tanabe N, Hiraoka E, Hoshino M, Deshpande GA, Sawada K, Norisue Y, Tsukuda J, Suzuki T: Progressive ischemic stroke due to thyroid storm-associated cerebral venous thrombosis. Am J Case Rep 2017;18:194-197.

7 Shi Z, Zhang X, Chen Z, Liebeskind DS, Lou M: Elevated thyroid autoantibodies and intracranial stenosis in stroke at an early age. Int J Stroke 2014;9:735-740.

-8 Wollenweber FA, Zietemann V, Gschwendtner A, Opherk C, Dichgans M: Subclinical hyperthyroidism is a risk factor for poor functional outcome after ischemic stroke. Stroke 2013;44:1446-1448.

-9 Selmer C, Olesen JB, Hansen ML, Lindhardsen J, Olsen AM, Madsen JC, Faber J, Hansen PR, Pedersen OD, Torp-Pedersen C, Gislason GH: The spectrum of thyroid disease and risk of new onset atrial fibrillation: a large population cohort study. BMJ 2012;345:e7895.

10 Sheu JJ, Kang JH, Lin HC, Lin HC: Hyperthyroidism and risk of ischemic stroke in young adults: a 5-year follow-up study. Stroke 2010;41:961-966.

11 Rastogi L, Gupta S, Godbole MM: Pathophysiological basis for thyrotoxicosis as an aggravating factor in post-ischemic brain injury in rats. J Endocrinol 2008;196:335-341.

12 Squizzato A, Gerdes VE, Brandjes DP, Büller HR, Stam J: Thyroid diseases and cerebrovascular disease. Stroke 2005;36:2302-2310.

13 Rocha MS, Brucki SM, Ferraz AC: Cerebral vasculitis and Basedow-Graves disease: report of two cases. Arq Neuropsiquiatr 2001;59:948-953.
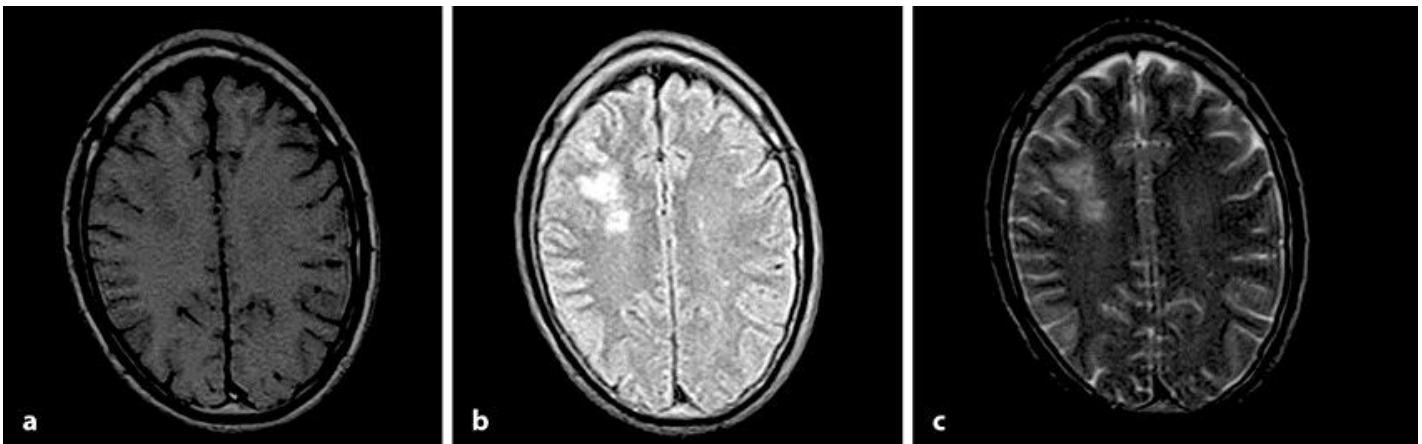

Fig. 1. T1 (a), FLAIR (b), and T2 (c) magnetic resonance imaging confirmed the ischemic area in the right frontal and parietal lobe. 


\section{Case Reports in Neurology}
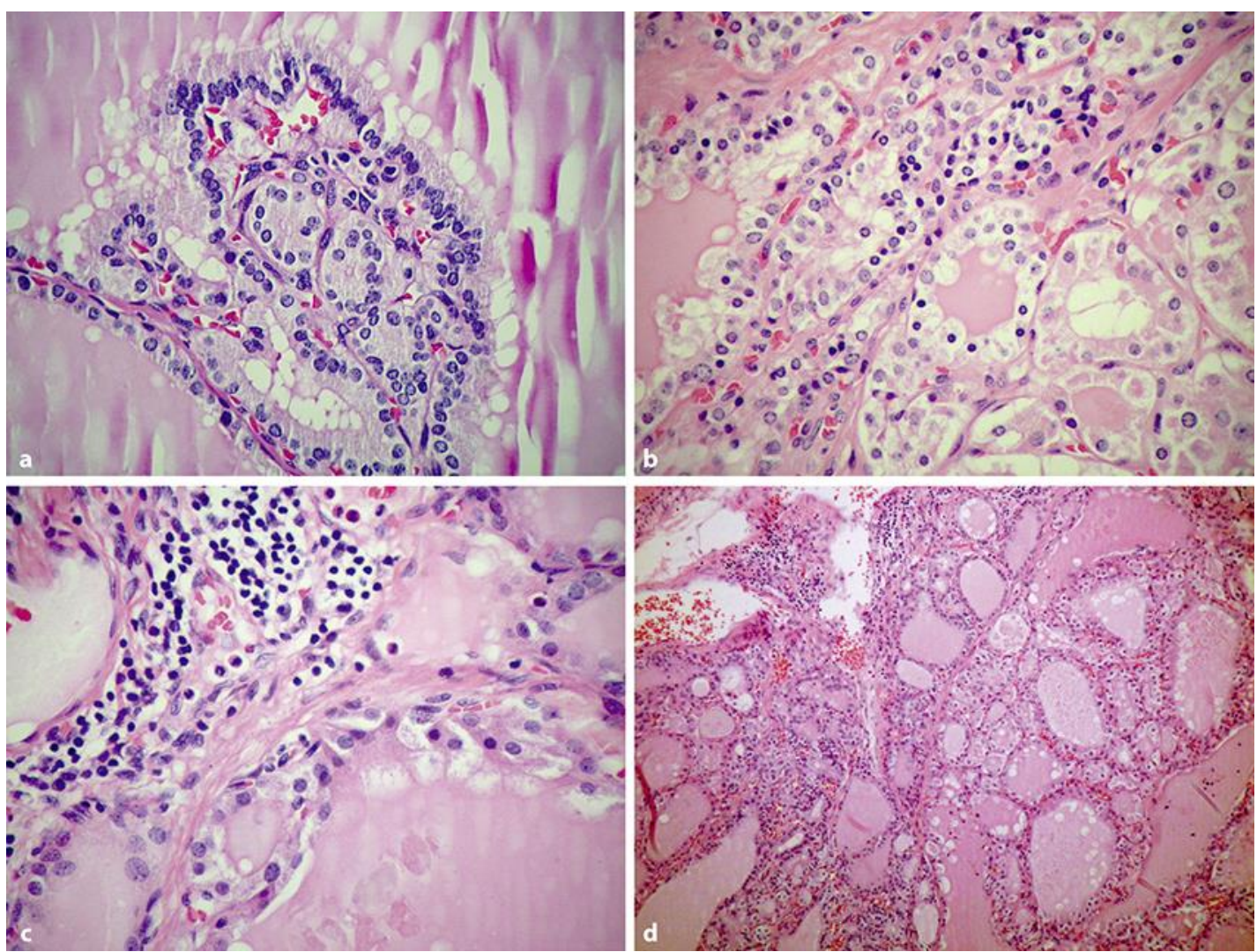

Fig. 2. a Thyroid with follicles showing hyperplastic epithelium, filled with colloid with intense vacuolization in the periphery evidencing morphological signs of hyperfunction. HE. $\times 100$. b Details of the lymphocytic infiltrate that diffuses through the follicles. HE. $\times 200$. c Follicular epithelium with a hyperplastic appearance, with cells showing granular and oxyphylic cytoplasm and colloid fluid and vacuolated at the periphery. Presence of lymphocytes in the interstitium. HE. $\times 200$. $d$ Details of the hyperplastic epithelium and its papillary projection. HE. $\times 200$. 


\section{Case Reports in Neurology}

Bazan et al.: Stroke in a Young Man Secondary to Paroxysmal Atrial Fibrillation and

Thyrotoxicosis: A Case Report

Table 1. Previous studies on stroke and thyroid dysfunction

\begin{tabular}{|c|c|c|c|c|}
\hline $\begin{array}{l}\text { First author [Ref.], } \\
\text { year }\end{array}$ & $\begin{array}{l}\text { Study } \\
\text { design }\end{array}$ & Population & Thyroid dysfunction & Outcomes and conclusions \\
\hline $\begin{array}{l}\text { Tanabe [6], } \\
2017\end{array}$ & $\begin{array}{l}\text { Case } \\
\text { report }\end{array}$ & $\begin{array}{l}\text { A } 49 \text {-year-old Japanese } \\
\text { female patient with cerebral ve- } \\
\text { nous thrombosis (CVT) }\end{array}$ & Thyroid crisis & $\begin{array}{l}\text { Clinicians should consider CVT when } \\
\text { they encounter a stroke in a patient } \\
\text { with hyperthyroidism }\end{array}$ \\
\hline Shi [7], 2014 & $\begin{array}{l}\text { Retro- } \\
\text { spective }\end{array}$ & $\begin{array}{l}351 \text { first-onset ischemic stroke } \\
\text { patients }\end{array}$ & $\begin{array}{l}\text { Elevated thyroid } \\
\text { autoantibodies }\end{array}$ & $\begin{array}{l}\text { Thyroid autoantibodies may be associ- } \\
\text { ated with the presence of intracranial } \\
\text { stenosis in young patients after stroke }\end{array}$ \\
\hline $\begin{array}{l}\text { Wollenweber } \\
\text { [8], } 2013\end{array}$ & $\begin{array}{l}\text { Single- } \\
\text { center } \\
\text { cohort }\end{array}$ & 165 patients with ischemic stroke & $\begin{array}{l}\text { Hyperthyroidism: } 11.5 \% \\
\text { Hypothyroidism: } 13.9 \%\end{array}$ & $\begin{array}{l}\text { Hyperthyroidism is a risk factor for } \\
\text { poor outcome } 3 \text { months after ischemic } \\
\text { stroke }\end{array}$ \\
\hline Selmer [9], 2012 & Cohort & $\begin{array}{l}586,460 \text { adults who had their } \\
\text { thyroid function evaluated for the } \\
\text { first time and who were without } \\
\text { previously recorded thyroid dis- } \\
\text { ease or atrial fibrillation (AF) }\end{array}$ & Thyrotoxicosis & $\begin{array}{l}\text { The risk of AF was closely associated } \\
\text { with hyperthyroidism }\end{array}$ \\
\hline Sheu [10], 2010 & Cohort & $\begin{array}{l}\text { 3,176 patients with } \\
\text { hyperthyroidism and } 25,408 \\
\text { without hyperthyroidism }\end{array}$ & Hyperthyroidism & $\begin{array}{l}\text { Hyperthyroidism is associated with an } \\
\text { increased risk for ischemic stroke in } \\
\text { young adults }\end{array}$ \\
\hline Rastogi [11], 2008 & $\begin{array}{l}3 \text { Experi- } \\
\text { mental }\end{array}$ & $\begin{array}{l}\text { Euthyroid }(n=15) \text { and } \\
\text { thyrotoxic }(n=60)\end{array}$ & Thyrotoxicosis & $\begin{array}{l}\text { High mortality in hyperthyroid animals } \\
\text { after stroke }\end{array}$ \\
\hline $\begin{array}{l}\text { Squizzato } \\
{[12], 2005}\end{array}$ & $\begin{array}{l}\text { Litera- } \\
\text { ture } \\
\text { review }\end{array}$ & $\begin{array}{l}\text { Studies on the relationship be- } \\
\text { tween thyroid diseases and cere- } \\
\text { brovascular diseases }\end{array}$ & $\begin{array}{l}\text { Hyperthyroidism and } \\
\text { hypothyroidism }\end{array}$ & $\begin{array}{l}\text { In subclinical hyperthyroidism, the } \\
\text { incidence of AF is increased, and in } \\
\text { overt hyperthyroidism, cardioembolic } \\
\text { stroke is associated with thyrotoxic AF }\end{array}$ \\
\hline Rocha [13], 2001 & $\begin{array}{l}\text { Case } \\
\text { report }\end{array}$ & $\begin{array}{l}\text { Report of } 2 \text { patients with cerebral } \\
\text { vasculitis and Basedow-Graves } \\
\text { disease }\end{array}$ & Basedow-Graves disease & $\begin{array}{l}\text { There is a possible pathogenic link } \\
\text { between Graves' disease and cerebral } \\
\text { vascular disorders, possibly through a } \\
\text { common autoimmune mechanism }\end{array}$ \\
\hline
\end{tabular}

